\title{
Dialogue of Life and Its Significance in Inter-Religious Relation in Malaysia
}

\author{
SURAYA SINTANG*, AZIZAN BAHARUDDIN \& \\ KHADIJAH MOHD KHAMBALI@HAMBALI ${ }^{1}$
}

\begin{abstract}
Dialogue of life is a form of inter-religious dialogue which commonly takes place at any place and any time. It is a dialogical relation to promote amicable relation with people from different religions. It begins when one encounters, lives and interacts with the others and participates in daily life activities together. It is a social interaction which shows the involvement of non-elite participants in the inter-religious dialogue at the grass roots level. The nonelite participation in the inter-religious dialogue is necessary to accommodate the challenge of pluralistic society. This kind of process which involves the social interaction in everyday activity is known as a dialogue of life. Those activities can be seen in the life experience of living together with mix-faith family, celebrating festivities and wedding ceremony as well as doing (running) business with the other religious communities. The aim of this paper is to elucidate the concept of dialogue of life and how this dialogue has a significant impact on encouraging positive interaction among people of different religions in Malaysia.
\end{abstract}

Keywords: dialogue of life, inter-religious relation, Malaysia, non-Muslim.

Malaysia is one of the Southeast Asian countries that is known for its diversity in religion and culture. The diversity reflects not only at its various languages and multi-racial society but also in multi-religious adherents of the people. Osman (2009) argues that the diversity of religion in Malaysia is the main social challenge needed to be handled effectively. This is more emphasized by Chandra (2010) who said that creating an atmosphere that is conducive to inter-religious understanding and harmony is a challenge ${ }^{i}$ to Malaysian society. Creating harmony is the main agenda for inter-religious dialogue and this can be applied in a roundtable discussion among the religious elites. In the modern pluralistic society of practical living together, a dialogue aims to learn something different from the others (Swidler 2003) as well as to get to know the others (Shehu 2008; Berghout 2008; Smith, 2007; Osman 2006; Azizan 2005; Khadijah 2004) as one whole human family.

${ }^{1}$ Suraya Sintang*(Corresponding author), Ph.D. Lecturer at Universiti Malaysia Sabah, 88400 Kota Kinabalu, Malaysia. Email: suraya@ums.edu.my; Azizan Baharuddin, Ph.D. Professor at University of Malaya, 50603 Kuala Lumpur, Malaysia. Email: azizanb@um.edu.my; Khadijah Mohd Hambali, Ph.D. Assoc. Prof. at Academy of Islamic Studies, University of Malaya, 50603 Kuala Lumpur. Email: ijamh@um.edu.my.

https://doi.org/10.24035/ijit.2.2012.007 
Getting to know the others is a dialogical relation to promote amicable relationship with people of different religions. It begins when one encounters, lives and interacts with the others and participates in daily life activities together. The social interaction marks the involvement of non-elite participants in the inter-religious dialogue at the grass roots level. The non-elite participation in inter-religious dialogue is necessary to accommodate the challenge of pluralistic society. The process of social interaction in everyday activity is known as a dialogue of life. Those activities can be seen in the life experience of living together with mix-faith family, celebrating festivals and wedding ceremony as well as doing (running) business with other religious communities. Thus, the aim of this paper is to elucidate the concept of dialogue of life and how this dialogue has a significant impact on encouraging positive interaction between people of different religions in Malaysia.

\section{Inter-Religious Relation in Malaysia}

The formation of multi-religious society of Malaysia began when Chinese and India descent were given citizenship in the early sixties (Chandra 2010). It was described by Chandra as, "one of the greatest concessions that some indigenous people have made to non-indigenous communities in the entire history of humankind." It also shows the accommodation and acceptance ${ }^{\mathrm{ii}}$ of Malay-Muslims towards the non-Malay, non-Muslim communities as part of the Malaysian population. Therefore, the readiness of living together with people of different religions has begun as early as the formation of Malaysia which leads to the creation of multi-ethnic and multi-religious society comprising three big races and religions - Malay-Muslims, Chinese-Buddhist and Indian-Hindus. There are also other dominant indigenous community of East Malaysia in Sabah and Sarawak which consist of Kadazandusun-Christians and Iban-Christians.

It is a challenge to Malaysia to maintain harmony and peaceful coexistence in a multi-religious society. It becomes more complex when dealing with inter-religious issues because the inter-religious issues are no longer dealing with theological problems; rather it is related more to the problem of living together and social interaction. Mohd Farid Mohd Shahran (2008) highlights the inter-religious issues pertaining to the problem of living together have dealt with the issue of sitting the area of building religious worship, incongruence between the system of civil and syariah courts as well as the religious conversion either to enter or leave any particular religion. The other issues concern on the matters of halal certificate by non-Muslim businessmen, the usage of Arabic and Quranic terminologies, funeral process, Islamic propagation and so on.

Walters (2007) states that among the issues affecting Christian-Muslim relation in Malaysia is the state government carefully control the distribution of land to build nonMuslim places of worship and the allocation of land for non-Muslim cemeteries. It is because the land distribution for those purposes has to be given in fairness to the other religious communities of Buddhists and Hindus. As Islam is the official religion of the country and the religion of the majority, therefore, the distribution of land and fund are most likely been given to Muslims. This is not only the issue pertaining to inter-religious relation in Malaysia, yet, there are many more issues when dealing with Muslim-nonMuslim relation. Hence, Malaysian society has to learn to live together and begin to understand each other through dialogical relation in living together and social interaction. Chandra (2010) argues that if we fail to ensure easy and harmonious relations among the

https://doi.org/10.24035/ijit.2.2012.007 
diverse ethnic communities of our planet, it is unlikely that we will be able to guarantee the continuous survival of our planets.

In order to ensure the harmonious relation in multi-religious society of Malaysia, promoting dialogue at the grass root level can be a step to reach the goal because dialogue of life plays a major role in building bridges between people from diverse religious backgrounds. Dialogue of life is a real dialogue which involves the non-elite participants through daily life interactions and activities whether at various levels of individual, family, neighborhood, friendship or official assignments (Wan Ariffin 2011). The phenomenon of dialogue of life in Malaysian context can be seen in everyday activities of living together, celebrating religious festivities and social interaction at work and marketplace.

\section{Concept of Dialogue of Life}

Inter-religious dialogue takes many forms, but is essentially a conscious attempt to build bridges of understanding, respect, harmony, and friendship among religious communities. (http://www.newworldencyclopedia.org/entry/Inter-religious_Dialogue). One of the forms of interreligious dialogue is "dialogue of life" which involves daily life interaction between people of different adherents. The New World Encyclopedia recognizes the dialogue of life as the third trend of inter-religious dialogue for the new millennium. The first trend of interreligious dialogue is the continuing and developing instituitionalization of inter-religious dialogue. There are now national organizations that bring together members of the major world religions such as the Inter Faith Network for the United Kingdom, founded in 1987. The second trend is academic institutions which are involved in monitoring and reflecting the demography and other characteristics of religious pluralism. This significant trend finds its best example in the United States with the Pluralism Project initiated in 1991 at Harvard University (http://www.newworldencyclopedia.org/entry/Inter-religious_Dialogue).

Diana Eck (1986) identifies six types of dialogue, namely parliamentary, iii institutional, ,v $^{\text {theological, }}$ spiritualvi and inner dialogues ${ }^{\text {vii }}$ as well as dialogue in a community or dialogue of life. Eck defines dialogue of life or dialogue in community as inclusive categories that encompass most of the unstructured interaction between people of different traditions. These take place in markets and on street corners, at times of festivals, in the course of civic or humanitarian projects, and at times of community or family crisis. This sort of dialogue takes place as people in communities think together about violence, militarism, or economic depression. These dialogues happen spontaneously or of organized, concentrate on practical issues of common concern. Unfortunately, these spontaneous dialogues are rarely recognized and celebrated for their value, and organized community dialogues are more often precipitated by a problem or crisis.

Meanwhile, Cardinal Arinze, a former president of the Pontifical Council for Interreligious Dialogue (PCID), as described by Ugwoji (2008) identifies four forms of interreligious dialogue, i.e. dialogue of life, dialogue of collaboration, dialogue of theological discourse, and dialogue of religious experience. He describes dialogue of life as a form of inter-religious dialogue that is within the reach of anyone who lives or interacts with believers in a different religion. It is inter-religious relationship at the level of the ordinary relational situations of daily life: family, school, place of social or cultural contact, village meetings, workplace, politics, trade or commerce. When neighbors of differing religions are open to one another, when they share their projects and hopes, concerns and sorrows, they

https://doi.org/10.24035/ijit.2.2012.007 
are engaging in dialogue of life. They do not necessarily discuss religion, but they draw on the values of their different beliefs and traditions. This kind of dialogue implies concern, respect and hospitality towards one another. It leaves room for the other person's identity, modes of expression and values.

For Archbishop Marcell Zago as described by Haney (2009), the inter-religious dialogue refers to five forms of dialogue. Living dialogue or dialogue of life, dialogue of cooperation, ${ }^{\text {viii }}$ dialogue of religious experience, ${ }^{\text {ix }}$ theological dialoguex ${ }^{x}$ and official dialogue are among religious authorities. ${ }^{\mathrm{xi}}$ Archbishop Marcell Zago states that the most common form of interfaith dialogue is that practiced by ordinary people in the everyday marketplace situations. Haney (2009) describes that in practice, dialogue of life or living dialogue consists of respecting people as believers on a neighborly basis and establishes constructive and positive relations. Certainly, because of the religious diversity that marks most urban communities, people of different faith traditions interact in ways that may encourage a deeper understanding of other people's experiences and the way they live their lives. This form of living dialogue is most evident among those who work, study, transact business and live in urban communities. Not only does this approach foster mutual witness, it also causes one to come to a deeper understanding of his or her own faith and religious identity.

The dialogue of life is further explained by Ubaka (2003), who said that this type of dialogue is an informal one, where people express their views, share their joys and sorrows and discuss their problems freely. They do this to learn from one another as well as to establish a loving relationship with one another. It is interesting to note that even at this level some form of discussion on one's relationship with God will take place because people are basically religious, and matters of religious interest form part and parcel of their daily discussion. Pratt (2010) argues that Christians and Muslims are to be people of dialogue for whom the first priority is the dialogue of life, where he explained as 'a positive acceptance, interaction and cooperation by which we bear active witness, as believers, to the ideals to which God has called us'. The speech conveyed by Arinze at ASEAN conference of ChristianMuslim relation in Pattaya, Thailand in 1996 states that in order to live in peace and harmony, to remove discrimination and to build up their societies together, it is necessary for Christians and Muslims to meet each other in a climate of deep mutual respect and esteem. In this respect, Arinze defines dialogue of life as wherein participants live and work together and enrich one another through the faithful practice of the values of religion, without the necessity of formal discussion.

The concept of dialogue of life for Hensman (1999) is different in nature because it was always there. It was unearthed, recognized, acknowledged rather than constructed since it is about how people live alongside with each other or against each other. They rub shoulders. It is sometimes concretively, sometimes abrasively. The dialogue of life can be messy. It does not easily fit into agendas. It simply happens. Ugwoji (2008) goes on to describe that dialogue at this level is a way of breaking down cultural biases and prejudices. It is a way of getting to know people of other faiths at the human level. This form of engagement will lead to next identities as dialogue of collaboration, where adherents of various religions cooperate for the promotion and human development and liberation in all of its forms. This form of dialogue is exemplified in social concerns inspired by religious motives, such as in the study and execution of development of projects and in initiatives to foster justice and peace. This reasoning will constitute good grounds for peaceful coexistence. 
It clearly states that the concept of dialogue of life consists some elements of daily interaction, namely encountering each other; involving non-elite participants from the ordinary people, who are not expert in religious teachings that are conducted in the form of informal conversation taking place at anytime and anyplace; and the people show their willingness to live together; the dialogue aims to know and learn from each other as well as to establish loving relationship regardless of their religious background. Most importantly this form of dialogue can be a mechanism to break cultural biases and prejudices among the people of living together. All these elements of dialogue of life are applicable to multireligious Malaysian society in which they are not only intermingled and integrate with each other, but also ready to live together in a mix-faith family, is willing to attend other religious ceremony and celebrate various festivals together as well as mix around with people from different religions.

\section{A Phenomenon of Dialogue of Life in Malaysia}

The term dialogue of life is still not widely used to display a phenomenon of living together and daily life interaction between people of different religions in Malaysia. Although the coexistence of Malaysian multi-religious society has begun since pre-independence when they frequently met and shared activities together, ${ }^{\text {xii }}$ we fail to recognize that this kind of social interaction is part of the interreligious dialogue operating at the grass roots level. It is actually an informal dialogue or conversation between the people of different religions either within the circle of family members or community.

This informal conversation can be applied in the everyday activities of living together with mix-faith family as experienced by Muslim converts in Malaysia. An interview with selected Muslim converts in Kota Kinabalu, Sabah was carried out to share their experience of living together with their non-Muslim family of origin. This can be illustrated in the following narrative transcriptions:

i) Almost a year after becoming Muslim, I see some changes in my family. For example, they don't switch off the TV when the azan (the call for prayer) is on air like what they did previously. When I watch a movie or drama conveying the message of Islam, I will tell them what it is about and they are ready to listen to my explanation. Until now, they know a little bit about Mecca and the reasons why Muslims perform Hajj there.

During Christmas, I go back to kampung for family gathering. It is my routine to prepare meals and cookies for Christmas and I did it almost every year. I explained to them that I choose Islam because I feel comfortable being a Muslim. My mum always sees me putting Yaasin (a verse in Quran) beside my bed.

(Source: Interview at May, 24th 2008 at the respondent's house, Apartment University, Iban/F-Twu-Resp7)

ii) After converting to Islam, I didn't think of wearing headscarf. My father said, "You have to make some changes after you convert to

https://doi.org/10.24035/ijit.2.2012.007 
Islam. Don't stick to your old dress code. It's better if you wear headscarf.

One day, my father visited me and he didn't see me performing solat. He said,"why don't you perform prayer, the mosque has called for prayer (azan)?"

He also used to ask me during Ramadhan when he saw me eating. I replied,"I didn't fast because I am having my menses." My father said, "Was it not allow to fasting when you are having your menses?"

"Yes," I said. He then asked me again, "Why is it not allowed? He then advised me not to quit fasting after my menses ends.

I don't feel any challenge or negative response from my family after converting to Islam. I get full support from them. For example, my father bought me a headscarf to wear and advise me not to wear any sleeveless outfit anymore. He always told to me to follow the teaching of my new religion. He used to tell me that he is proud of me of being his daughter even though we are no longer in the same religion.

(Source: Interview on July 24th 2009 at religious class of Teratak Fitrah, Rgs/F-Kdt-Resp36).

The above findings show the element of dialogue of life within the context of living together with mix-faith family as experienced by Muslim converts in Malaysia. The Muslim converts are no longer in the same religion with their family of origin, yet they are still willing to stay together with them. It is interesting to highlight that the non-Muslim family begins to understand Islam through the experience of living together. In the sense that faceto-face interaction, spontaneous conversation and sharing daily life activities together are part of the process of dialogue of life in the family circle of different religions. The experience of Muslim converts living together with their family of origin shows that the dialogue of life can be a mechanism to clarify any misunderstanding arises after converting to Islam. It can be said that the longer they live together with their non-Muslim family, the more they would explain the teachings of Islam to them. In other words, the family of origin will understand Islam in a practical way by witnessing how Islam is applied in everyday activities. Through the performance of solat (prayer), fasting and wearing hijab, Islam can be understood by the means of non-verbal communication. This is the way how the process of dialogue of life applicable in social interaction between Muslim-non-Muslim relation in Malaysia. The dialogue of life as experienced by Muslim converts displays the Malaysian experience of living together with different religious communities. It is the involvement of non-elite participant from the individuals who have converted to Islam to convey the message of Islam through informal conversation. The interaction in daily basis explains how the process of dialogue of life significantly influences the perception of the others towards Islam. The process of encountering the others even without the conversation has helped the non-Muslim family of Muslim converts understand Islam in a simple manner. Their understanding may be differ from the previous one which is more likely to perceive Islam in a negative way.

It is proof from the above cases that the family perception and suspicion of Islam has indeed changed through frequent explanation and the good deeds practiced by Muslim

https://doi.org/10.24035/ijit.2.2012.007 
converts. Nevertheless, the obstacle of living together in the mix-faith family of Muslim converts is unavoidable particularly at the beginning of transforming to the new spiritual life of Islam. However, it gradually reduces to be a more positive interaction through the constant and frequent encounter between the two parties of different religions. The element of dialogue of life can also be described in the celebration of religious festivals together. In Malaysia, it is a common situation to see the diverse community of religions sitting down together to have a meal at the festive seasons of Eid Fitri and Chinese New Year. Attending open houses for festive celebration is becoming a culture to strengthen the friendship between both parties of Muslim and non-Muslim ties. Therefore, celebrating other's festivals together is part of the process of dialogue of life in Malaysian style. It is not only by encountering the others have given them a chance to closely know each other, but also a platform to build loving relationships across the religious boundaries.

Besides that, the celebration is most obviously seen during the wedding ceremony particularly in the intermarriage parties. The intermarriage strengthens not only the family members of different races and religions but also enhances the close relationship between the two parties. Lindenberg (2009) said that intermarriage is seen as a positive sign of harmonious relations between different ethnic groups. It is also explained by Jones (2009) who said that inter-religious marriage is an important indicator of good relations between communities in religiously diverse countries. The intermarriage brings members of different religions to meet, interact and live together under one family. This encourages them to know each other not only knowing the names but also the customs and religious practices. Smith (2007) states that getting-to-know the others is a method of dialogue of life in building bridge between Christian-Muslim relations. It is about knowing the other; one decides to get married with those who are different in cultural and religious backgrounds. This phenomenon is a common practice among most of the native people in East Malaysia of Sabah and Sarawak.

Furthermore, the element of dialogue of life is obviously seen in the Malaysian diverse community in everyday business activities. Martinez (2008) argues that unlike many other societies, Malaysians have constant, real reminders that they are around someone of a different religion from different groups. They are comfortable with the element of exposure and inclusion. In fact Malaysians of different races and religions work together in offices and factories, use facilities together, travel together on public transport, take classes together, shop alongside each other, as well as buy and sell to each other. This is the way the process of dialogue of life is applied in everyday activities in multi-religious Malaysian society. They do not only know the others by name, but also accommodate to the other cultures and respect the way the others' practice of their religions. It can be said that the elements of dialogue of life in living together, celebrating festivals and sharing activities together are the beginning of a new understanding based on a reciprocal willingness to know and learn from each other.

\section{The Significance of Dialogue of Life for Inter-Religious Relation in Malaysia}

By promoting dialogue of life as a mechanism for social interaction in daily life activities in the diverse Malaysian society, it will gradually enhance mutual understanding and encourage people to be more graceful in their relations with others. It is also through the process of dialogue of life, people will be equipped with the ability of cultural literacy. By

https://doi.org/10.24035/ijit.2.2012.007 
cultural literacy, we mean that the members of society will develop their ability to appreciate and manage religious diversity in multicultural society. Osman (2008) states that this new cultural literacy is basically concerned with our capacity to learn about spiritual traditions other than our own, to know commonalities that bind all religions together and differences that set them apart. Moreover, the new cultural literacy is also about having the right attitudes toward both commonalities and differences. Therefore, the dialogue of life as practiced by the Malaysian diverse community to live together, to celebrate other's festivals and to mix around with those who are different in religious background, are part of the way to create cultural literacy and build bridges to the others.

The significance of dialogue in bridging the gap and rectifying the human relation is further discussed by Berghout (2008), where he said that it is through dialogue that one can know the causes and reasons of the breakdown in human relations and communications. He further continues that it is through open, free and sincere dialogue that people can know what went wrong in their course of actions. It is only through just and responsible dialogue that human problems can be tackled efficiently and human wisdom can be shared and disseminated. Therefore, promoting dialogue of life at the local level is designed to encourage peaceful co-existence in multi-religious and multi-ethnic society and to work harmoniously among them. Malaysia needs such kind of dialogue so that the people know the others well and learn to share the commonalities together and to respect the differences.

As a conclusion, it is firmly stressed that the dialogue of life is not just to describe the conceptual meaning of inter-religious dialogue at the grass roots level. Rather, it is a dialogue to encourage positive relation to the people of different religions. It is because the dialogue of life promotes the people to integrate and intermingle with the others in everyday activities as they frequently encounter and interact with each other at any place and any time. The process of dialogue of life in Malaysia is obviously seen in the mix-faith family of Muslim converts and the study shows that the members of the family are willing to live together under one roof. The process can also be seen in the celebration of festive seasons together, where they have a meal and sit together as friends and relatives. Furthermore, the dialogue of life in everyday business is a routine for the people of all races and religions in Malaysia. The differences in religions do not make them feel isolated and hesitate to mix around with the others. In fact, the dialogical process through the process of daily live interaction will overcome prejudice and misunderstanding of the other. Therefore, the dialogue of life is significant for engaging the quest to improve human community and encourages people to coexist in harmony.

\section{References}

Azizan Baharuddin. 2005. Dialog Peradaban: Perspektif global dan lokal. In. Azizan Baharuddin, Mohamad Khairudin Mohamad, Faridah Noor Mohd Noor, Ahmad Syahir Sarani (Eds.). Dialog Peradaban: Peranan dan Kepentingannya di Malaysia (pp.16-20). Kuala Lumpur: Institut Perkembangan Minda (INMIND) dan Pusat Dialog Peradaban Universiti Malaya.

Berghout, A. 2008. Meeting the challenges of dialogue: Need for civilisational vision and cultural transformation. In. T.W. Simon \& Azizan Baharuddin (Eds.). Dialogue of

https://doi.org/10.24035/ijit.2.2012.007 
Civilizations and the Construction of Peace. (pp. 140-172). Kuala Lumpur : Pusat Dialog Peradaban, Universiti Malaya.

Chandra Muzaffar. 2010. A Plea for Empathy: The Quest for Malaysian Unity. Kuala Lumpur : Zubedy (M) Sdn Bhd.

Eck, D. 1986. What do we mean by Dialogue? Current Dialogue. 11: 5-11.

Haney, M. S. 2009. Envisioning Islam: Imam Mohammed and Interfaith Dialogue. The Muslim World. 99: 622-633.

Hensman, J. M. 1999. Beyond talk: The dialogue of life as the locus of non-verbal interreligious dialogue. East Asian Pastoral Review. 36(3): 323-337.

http://www.newworldencyclopedia.org/entry/Inter-religious_Dialogue.

Jones, G.W., Chee, H.L., Maznah Mohamad (Eds.). 2009. Muslim-non-Muslim Marriage:Political and Cultural Contestations in Southeast Asia. Singapore: Institute of Southeast Asian Studies.

Khadijah Mohd. Hambali. 2004. Budaya 'Kenal-Mengenali' dalam pembinaan ummah. In Mohd. Fauzi Hamat, Mohd Fakhrudin Abd. Muki, Che Zarrina Sa'ari (Eds), Pemikiran Islam dan Cabaran Semasa. pp.259-272. Kuala Lumpur: Jabatan Akidah dan Pemikiran Islam, Akademi Pengajian Islam, Universiti Malaya.

Lindenberg, J. 2009. Inter Ethnic Marriages and Conversion to Islam in Kota Bharu. In C. a. Jones, Muslim-non-Muslim Marriage: Political and Cultural Contestations in Southeast Asia. Singapore: Institute of Southeast Asian Studies.

Martinez, P. 2008. A case-study of Malaysia: Muslim-Christian dialogue and partnership, possibilities and problems with suggestions for the future. In. T. W. Simon \& Azizan Baharuddin (Ed.). Dialogue of Civilizations and the Construction of Peace. pp. 111141. Kuala Lumpur : Pusat Dialog Peradaban, Universiti Malaya.

Mohd. Farid Mohd. Shahran. 2008. Dialog antara agama dan peradaban: Pespektif agama dan tamadun. Kertas kerja Muzakarah Pendisiplinan Dialog Antara Agama dan Peradaban. 22 Januari di Institut Kefahaman Islam Malaysia (IKIM), Kuala Lumpur.

Osman Bakar. 2006. The Qur'an on Interfaith and Inter-Civilizational Dialogue: Interpreting a Divine Message for Twenty-first Century Humanity. International Institute of Islamic Thought Malaysia (IIITM) and the Institute for Study of the Ummah and Global Understanding (ISUGU).

Osman Bakar. 2009. Konsep Tamadun Malaysia kesatuan dalam kepelbagaian. In Hashim Ismail \& Raihanah Abdullah (Eds.), Permuafakatan dan Kerukunan Teras Peradaban Malaysia. pp. 1-9. Kuala Lumpur: Akademi Pengajian Melayu dan Pusat Dialog Peradaban, Universiti Malaya

Pratt, D. 2010. The Vatican in dialogue with Islam: inclusion and engagement. Islam and Christian-Muslim Relations. 21(3), 245-262.

Shehu, F. M. 2008. Nostra Aetate and Inter-Religious Dialogue: An Islamic Perspective. Kuala Lumpur: International Islamic University Malaysia Press.

Smith, J. I. 2007. Muslims, Christians and the Challenges of Interfaith Dialogue. New York: Oxford University Press.

Swidler, L. 2003. Dialog in Malaysia and the Global Scenario. Siri Monograf Pusat Dialog Peradaban. No. 1. Kuala Lumpur: Pusat Dialog Peradaban, Universiti Malaya.

Ugwoji, M.C. 2008. Inter religious relations and solidarity: Contextualization the Vision of Francis Cardinal Arinze for religious education in Nigeria. Unpublished Thesis PhD (ProQuest), Fordham University New York 
Walters, A.S. 2007. Issues in Christian-Muslim relations: A Malaysia Christian perspectives. Islam and Christian-Muslim Relations. 18 (167), 67-83.

Wan Ariffin Wan Yon, Khadijah Mohd Hambali, Wan Nazarul Wan Abdul Latip, Sharifah Zakiah Wan Hassan, Ahmad Rozainni Ali Hasan. 2011. Bridging the MuslimChristian Relations Through Dialogue of Life: Muslim Perspective. International Conference on Social Science and Humanity, IPEDR, Vol.5 (2011), IACSIT Press, Singapore.

${ }^{\mathrm{i}}$ It is a challenge to address some of the so-called "sensitive issues" that impinge upon inter-religious ties. One of the sensitive issues is the issue of conversion since it lies on the principle of religious freedom and the right of a person to join or leave a faith without coercion or compulsion.

ii It was described by Chandra (2010) among the reasons why the Malays choose to accommodate the nonMalays are because the Malay elite realized that if they were not accommodated in one way or other there could be considerable social instability. They believed that the Chinese and Indians were crucial to some of the most important areas of the economy -rubber, tin and trade. It is also because of the communist threat that influence the response of the Malay elite to the question of non-Malay citizenship. Other than that, the Malay elite sees that it was not averse to accommodating the non-Malays. It was prepare to grant them citizenship provided it did not lead to the annihilation of the Malays themselves in their own homeland.

iii Parliamentary dialogue refers to large assemblies created for interfaith discussion. The earliest example was the World Parliament of Religion convened in Chicago in 1893. This type of meetings have become more frequent under the auspices of multi-faith organizations such as the World Conference on Religion and Peace and the British-based World Congress of Faiths.

iv Institutional dialogue indludes both the organized efforts by particular religious institutions, and in Southeast Asia, governments of nations that initiate and facilitate various kinds of dialogue. This type of dialogue seeks to establish and nurture channels of communication between various religious communities. This category encompasses much of the work carried out through the World Council of Churches (WCC) and the Vatican, the World Council of Muslims for Inter-religious Relations and others.

${ }^{v}$ A theological dialogue refers to particular elements found in interfaith encounter as well as the larger process of reflection among Muslims, Jews, Christians, Buddhists, Hindus and others. It includes structured meetings in which theological and philosophical issues are the primary focus of discussion.

vi Spiritual dialogue concerns with deepening spiritual life through interfaith encounter. This type of dialogue does not struggle overtly with theological problems or issues between communities of faith. Rather, it is designed as a means to nourish, expand and develop spirituality or the spiritual dimension of religious life.

vii Inner dialogue takes place in each of us. It operates in various dialogical encounters as well as in our process of thinking and reflection. It is intimately bound up with growth and change in the development of one's religious perspectives. It takes place in our minds and hearts when we read the scriptures of another religious tradition, or when we hear their call to prayer.

viii Dialogue of cooperation takes place as religious people commit to work on projects or address issues of common concern. The goal is to integrate the religious dimension and show its ability to impact life in a positive and meaningful way. It requires mutual respect among people whose religious commitments and affiliations are openly acknowledged and can involve laity as well as clergy. On a local level, there are many models in which Muslims and Christians have worked together to address issues of public violence, create programs to provide safe afterschool programs for children, and to address issues related to health

https://doi.org/10.24035/ijit.2.2012.007 
challenges. Organizations of Muslim women, such as Sisters United in humanity are often supportive of community-based initiatives by interfaith partners where there is mutual trust (Haney, 2009).

ix This type of dialogue is centered on an exchange or participation with regard to religious experience. For example, attending celebrations of birth, marriage, funeral. The other adherents show respect for what the other person regards as sacred (Haney, 2009)

${ }^{\mathrm{x}}$ It is important for several reasons. It supports the understanding and transmission of knowledge related to aspects of religious faith and also reveals an interpretation of what it means to live the faith at a deeper level. It also provides a public experience by which interfaith and interpersonal reflections are discussed in such a way that their social and theological importance and impact become clearer. Muslims are more attentive to this form of dialogue, which they consider to have a political and witness value. This form of interfaith and interreligious dialogue is most popular at universities with religiously diverse populations, interfaith offices and divisions within religious and social institutions where many cultures are represented, as well as among public interfaith affiliations and associations (Haney, 2009)

xi This kind of dialogue can be seen in the work of Imam Mohammed, a former leader of the Nation of Islam (NOI) in U.S. He was the son of the honorable Elijah Muhammad, founder of the Nation of Islam. Imam Mohammed has served not only as an active participant in official dialogues sponsored by religious authorities (Jewish, Catholic and Protestant), but has himself officialy initiated such dialogue; he participated in dialogue promoted by the Pontifical Council for Interreligious Dialogue, the World Council of Churches and several mainstream U.S. Protestant denominations. Long before his death, Imam Mohammed had been in discussion with Muslims and the Presbyterian ch (USA) and together they had identified the need for a four-year interfaith process that would bring together Presbyterian Christians and American Muslims (Haney, 2009).

xii Ghazali (2005) notes that the early history of Malaysia affirms the experience of interaction with people from world civilization began in eight century. It was stated that the interaction began with the arrival of Hindus, followed by Buddhists from the Indian continents, then the coming of Islam in the $13^{\text {th }}$ century from Arab peninsular and Persian. It was then the interaction spread widely with Christianity brought by the western power in $16^{\text {th }}$ and $17^{\text {th }}$ century.

https://doi.org/10.24035/ijit.2.2012.007 